Przemysław Kieliszewski (D) https://orcid.org/0000-0003-0154-7422

Uniwersytet im. Adama Mickiewicza w Poznaniu

e-mail: biuro@ponte.pl

Otrzymano/Received: 10.12.2020

Zaakceptowano/Accepted: 16.03.2021

Opublikowano/Published: 12.04.2021

\title{
Przywództwo instytucji artystycznej w czasie pandemii na przykladzie Teatru Muzycznego w Poznaniu
}

\section{Abstract \\ Leadership in an Artistic Institution during a Pandemic. Case Study of the Musical Theater in Poznań}

The article deals with the topic of leadership in a public cultural institution - a musical theater. The pandemic has highlighted the weakness or strength of such organizations, their passivity or proactivity. The strength of an institution lies in a team built by a reliable leader. The point of reference for the author are the leadership concepts formulated by prominent experts in management, such as Ken Blanchard or Jim Collins. A good leader creates a space for good communication, which then gives rise to an organizational culture that fosters creativity and shared responsibility. The article contains a summary of the research on organizational culture in the selected theater carried out using the Cameron and Quinn method and discusses the impact of their implementation on the development of the organization. Public cultural institutions can benefit greatly from business achievements in this area.

Keywords: leadership, leader, team management, communication, organizational culture, cultural institution

Słowa kluczowe: przywództwo, lider, zarządzanie zespołem, komunikacja, kultura organizacyjna, instytucja kultury 


\section{0pis praktyk w zakresie przywództwa i zarządzania w warunkach kryzysu (zmiany)}

Lockdown związany z pandemią COVID-19 wywołał wiele reakcji. We wszystkich instytucjach, w momencie ich zamknięcia 12 marca 2020 roku, pojawiła się konieczność przyjęcia nowej strategii działania. Dotyczy to szczególnie zarządzania zespołem artystycznym - w opisywanym przypadku zespołem Teatru Muzycznego w Poznaniu.

Przyjęcie strategii proaktywnej, otwarta komunikacja z zespołem i empatia wykazywana wobec pracowników miały dać zespołowi poczucie bezpieczeństwa. Proaktywność należy tu rozumieć jako branie spraw w swoje ręce, elastyczne planowanie, wyznaczanie i realizację celów, zaradność wynikającą z potrzeby chwili, uprzedzającą niepożądane skutki bierności.

Ta postawa wpływała na rzeczywistość w możliwie najszerszych kręgach działania. Znana w wojskowości zasada, że „zmiana decyzji świadczy o ciągłości dowodzenia”, przyświecała nam niejednokrotnie. W kontakcie $\mathrm{z}$ wieloma liderami organizacji w tym okresie można było obserwować przyjmowanie różnych postaw, w tym postawy reaktywnej. Wynikało to ze źle pojmowanej ostrożności, z lęku o popełnienie błędu, a także przerzucania decyzji i odpowiedzialności na czynniki zewnętrzne, w oczekiwaniu na rozporządzenia i wytyczne ze strony rządu lub samorządu.

Tymczasem z każdym tygodniem okazywało się, że niepewność narasta, decyzje nie są podejmowane, status pracowników przebywających w domach nie jest jasny, a powrót do „normalności” się oddala. Jak mówi bohater musicalu Rodzina Addamsów: „Normalnie? Czyli jak?” (fabuła musicalu, granego w Poznaniu, mierzy się m.in. z problemem społecznych norm i tego, co uważamy za normalne). Wśród wielu „ludzi kultury" funkcjonuje wciąż przekonanie, że teatrem, filharmonią, operą można zarządzać zupełnie inaczej niż inną organizacją. Wydaje się, że to w dużej mierze błędny pogląd. Metody w zakresie przywództwa czy budowania kultury organizacyjnej, opisane i sprawdzone w efektywnych organizacjach sektora prywatnego, warto i należy przenosić na grunt sektora publicznego, a więc również do instytucji kultury.

Lockdown spowodował na przykład znaczące zintegrowanie się liderów instytucji, a konkretnie dyrektorów teatrów muzycznych i operowych. Było to w dużej mierze wynikiem budowania kultury współpracy, która wcześniej została oddolnie zainicjowana warsztatami i szkoleniami, realizowanymi z pomocą Instytutu Muzyki i Tańca. Pozwoliło to stworzyć niezwykle cenną platformę codziennej wymiany doświadczeń, dzielenia się informacjami i ekspertyzami prawnymi, wywierania wpływu na kształt regulacji prawnych, w tym zmiany zapisu w rozporządzeniu Rady Ministrów. Słynna samotność liderów znalazła ostoję w gronie osób zmagających się z podobnymi wyzwaniami. Było to bardzo budujące doświadczenie.

W niniejszym artykule problematyzuję wiele doświadczeń dotyczących zarządzania publiczną instytucją artystyczną w czasie kryzysu pandemicznego z perspektywy 
dyrektora Teatru Muzycznego w Poznaniu. Jednocześnie chcę pokazać, jak można przenosić wartościowe doświadczenia zarządzania przedsiębiorstwem (sektor prywatny) do świata instytucji kultury (sektor publiczny). W kolejnych częściach artykułu analizuję kolejne istotne elementy: kulturę organizacyjną, komunikację, zespół i lidera. W swej analizie wykorzystuję przede wszystkim koncepcje przywództwa wypracowane przez klasyków zarządzania - Kena Blancharda czy Jima Collinsa.

\section{Kultura orģanizacyjna}

Otwartość i niemal natychmiastowe podjęcie regularnej komunikacji kryzysowej z zespołem Teatru Muzycznego w Poznaniu wyniknęły w sposób naturalny - z wprowadzonej w poprzednich latach - stopniowo, lecz konsekwentnie - zmiany kultury organizacyjnej. Kultura organizacyjna to „osobowość” organizacji i zbiór uważanych za oczywiste wartości, niekoniecznie zwerbalizowanych założeń, elementów pamięci zbiorowej oraz wspólnych oczekiwań i definicji podzielanych przez członków organizacji, jak to definiują w swym klasycznym dziele Kin S. Cameron i Robert E. Quinn [2003, s. 24]. Dowodzą też, że kultura organizacyjna odzwierciedla dominujące w organizacji poglądy, wzmacnia trwałość systemu społecznego w jej obrębie, jest źródłem nie do końca uświadomionych, często nieskodyfikowanych, a stosowanych w organizacji zasad postępowania. Kultura organizacyjna wyraża się w podzielanych przez członków organizacji wartościach, w języku i symbolach, obowiązujących metodach postępowania, rutynowych procedurach, dominujących stylach kierowania pracownikami, a także w tym, co zespół uważa za miarę swojego sukcesu [Cameron, Quinn 2003, s. 24-25]. Nie chodzi jednak o kopiowanie „osobowości” biznesowej do publicznej instytucji kultury, ale o wykorzystanie narzędzi, które mogą usprawnić i usprawniły działanie teatru.

Zmiana ta dokonała się najpierw jako karkołomny proces przeobrażenia Teatru Muzycznego w Poznaniu ze sceny o profilu operetkowym w scenę o profilu musicalowym. Wiązało się to z budowaniem nowej marki teatru od 2013 roku oraz ze zmianą dużej części zespołu artystycznego i administracyjnego. W drugim etapie, w 2016 roku, przeprowadzono badanie opinii członków zespołu, służące postawieniu diagnozy i zdefiniowaniu nowej kultury organizacyjnej. Pojawił się zestaw oczekiwań wobec lidera i organizacji. Pamiętam rozmowy inicjujące $\mathrm{z}$ autorami projektu [Diagnoza 2016], którzy kilkukrotnie pytali mnie, czy jestem gotowy usłyszeć trudne rzeczy o swoim stylu przywództwa, bo badanie z pewnością je wykaże. Nie pomylili się. Analiza dokumentów i procedur, dobrowolne ankiety wśród połowy pracowników, wywiady z kierownikami działów, członkami dyrekcji oraz obserwacja uczestnicząca badaczy stanowily metodologiczne podstawy diagnozy kultury organizacyjnej w modelu wartości konkurujących, opracowanym przez Camerona i Quinna. Model ten pozwala przyporządkować kulturę badanej organizacji do jednego z czterech głównych typów 
kultury: hierarchii, rynku, adhokracji lub klanu. Każdy z nich jest oparty na innych kluczowych i przeciwstawnych wartościach, wyznaczających sposoby postępowania organizacji w różnych aspektach. W celu zbudowania modelu przeprowadzono analizę statystyczną 39 wskaźników efektywności organizacji, a z nich 2 wymiarów, pozwalających podzielić te wskaźniki na 4 grupy. W pierwszym wymiarze konkurują ze sobą kryteria: elastyczność i swoboda działania ze stabilnością i kontrolą. Drugi wyróżniony wymiar zderza ze sobą orientację na sprawy wewnętrzne, integrację i jedność zespołu z orientacją na pozycję organizacji w otoczeniu, jej zróżnicowanie i rywalizację. W Teatrze Muzycznym analizie poddano: dominujący typ kultury w organizacji, rozbieżności pomiędzy rzeczywistą a pożądaną kulturą organizacji, siłę danego typu kultury i jej zgodność wewnętrzną.

\section{BADANIE KULTURY ORGANIZACJI - WYNIKI BADAŃ Siła danego typu kultury}

Podsumowanie: All (liczba badanych - 45)

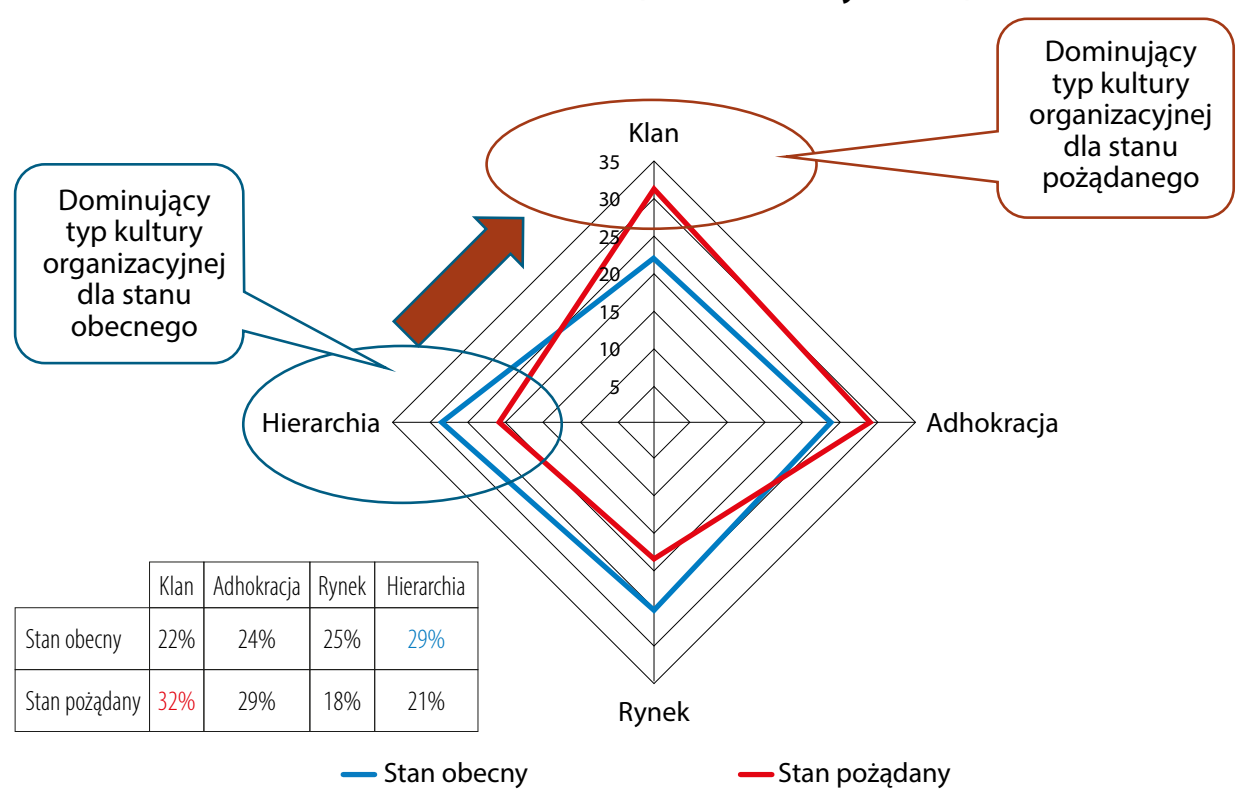

Rysunek 1. Diagnoza kultury organizacyjnej w Teatrze Muzycznym w Poznaniu

Źródło: Diagnoza kultury organizacyjnej Teatru Muzycznego w Poznaniu. Zespołowy projekt konsultingowy [2016].

Diagnoza ówczesnego stanu (rysunek 1) określiła dominujący typ kultury hierarchicznej. Wynikało to w dużej mierze ze zmiany przywództwa i jego stylu w 2013 roku po 23 latach zarządzania teatrem przez inną osobę - artystę. Jednak różnice pomiędzy pozostałymi typami kultur nie przekraczały $20 \%$, co wskazywało 
na potrzebę w miarę równego akcentowania każdego z czterech jej typów. Dla stanu pożądanego uwidoczniła się dominacja potrzeby zmiany w kierunku kultury klanu (poczucia bezpieczeństwa w życzliwym otoczeniu) i adhokracji (możliwości większej swobody działania ad hoc). Różnice pomiędzy skrajnymi obszarami doszły do 35\%. Jedynym wyjątkiem była płaszczyzna stylu przywództwa, gdzie wykazano (o dziwo) oczekiwanie wzmocnienia stylu hierarchicznego. Powyższe zostało potwierdzone w pogłębionych wywiadach z kadrą kierowniczą, która wskazywała na wysoką świadomość zespołu odnośnie do reżimów i dyscypliny terminowej realizacji zadań (charakter świadczonych usług nie przewiduje możliwości opóźnień w realizacji zadań, w tym terminów premier, planowanych z dużym wyprzedzeniem).

Wyniki badań sprowokowały już wówczas wiele przemyśleń i działań w kierunku oczekiwanej „klanowości”, a były to:

- ogłoszenie na koniec sezonu wewnętrznego konkursu na „Spektakulora” (i kilka pokrewnych kategorii) - osobę, która wyróżniła się swym zaangażowaniem i działaniami i osiągnęła ich spektakularny efekt. Wyniki zostały ogłoszone podczas zabawy kończącej sezon artystyczny;

- wyjazd do Kołobrzegu ze spektaklem Skrzypek na dachu, połączony z elementami integracyjnymi - ogniskiem, tańcami, wspólną kąpielą w morzu;

- zakup postulowanych przez zespół poduch, ułatwiających wypoczynek w przerwach między próbami lub spektaklami.

Ważnym elementem integrującym zespół z liderem była też wspólna praca podczas prób do koncertu sylwestrowego i występ wokalno-choreograficzny dyrektora, niewykonującego zawodu artystycznego. Z pewnością przyczyniło się to do wzrostu wzajemnej empatii i zrozumienia. Wiele podobnych działań oraz otwarta komunikacja zacieśniły relacje w samym zespole, dały jego członkom poczucie bezpieczeństwa oraz zbudowały relacje zaufania.

W związku z tym całkowicie naturalne było zorganizowanie od samego początku pandemii spotkań z pracownikami za pomocą platformy Zoom. Codzienne poranne rozgrzewki, prowadzone dla chętnych przez dyrektor artystyczną Paulinę Andrzejewską-Damięcką i innych członków zespołu artystycznego, budowały więzi oraz zapewniały wsparcie. Cotygodniowe spotkania lidera z zespołem szybko stały się tradycją i gromadziły ok. 2/3 całego zespołu. Dotyczyły planowanych działań zarobkowych, ochrony socjalnej pracowników w następstwie odwołanych spektakli, bieżącej sytuacji epidemiologicznej i wniosków wynikających z tego dla pracy zespołu. Po każdym spotkaniu wysyłano wszystkim szczegółowy komunikat. Spotkania te miały również charakter terapeutyczny i pozwalały podzielić się troskami, które okazywały się wspólnym doświadczeniem, czy zadbać o osoby, które w danym momencie na przykład nie mogły wychodzić z domu z powodu kwarantanny. Na te spotkania zapraszany był też zaprzyjaźniony lekarz, a także psycholog, którzy - oprócz części wykładowej z zakresu profilaktyki zdrowia, radzenia sobie z wyzwaniami choroby i izolacji - służyli indywidualną pomocą. 


\section{Komunikacja}

Jedną z kluczowych rekomendacji, wynikającą z omawianego badania kultury organizacyjnej w 2016 roku, była poprawa komunikacji w zespole.

Już wówczas szczegółowe rekomendacje zakładały zwiększenie ilości i jakości interakcji dyrekcji z pracownikami. W pewnym sensie pandemia pomogła w znalezieniu wspólnego i powszechnego kanału komunikacji z i między pracownikami. Choć już wcześniej wdrożyliśmy regularne krótkie spotkania dotyczące konkretnych projektów (tzw. standingi), które gromadziły pracowników działów, między innymi koordynacji pracy artystycznej, marketingu, biura obsługi widza, impresariatu, techniki, administracji, zostały one przeniesione na platformę zdalnej komunikacji. Stopniowo okazało się, że udział dyrekcji w tych spotkaniach nie jest kluczowy. Sposób ich prowadzenia wytworzył rodzaj współodpowiedzialności pracowników za projekty. Poszczególne zadania działów są zawsze omawiane w kontekście działań innych osób. Etapowa realizacja każdego zadania i czynności pośrednich jest monitorowana na bieżąco przez cały zespół, a ewentualne opóźnienia są korygowane niekoniecznie przez lidera, ale przez członków zespołu, gdyż wpływają na postęp lub płynną realizację ich zadań.

Dzięki systemowi tych spotkań i zmianie zaangażowania pracowników wymarzone słowa lidera, jak współodpowiedzialność czy stała pozioma komunikacja w zespole, zaczęły się ucieleśniać. A deficyt tych spotkań pod koniec 2020 roku, spowodowany nagromadzeniem realizacji projektów, dał się we znaki bardziej zespołowi niż liderowi. Członkowie zespołu, szczególnie ci, którzy zawsze przejmują odpowiedzialność za „niezagospodarowane pola”, zaczęli odczuwać skutki braku tych spotkań i sami zawnioskowali o ich ponowne wyznaczanie.

Świadczy to o dużej świadomości i doświadczeniu tych członków zespołu w zakresie skuteczności procesów zachodzących w organizacji, odpowiedzialności za nią i za osiąganie jej celów. Świadczy również o tym, że kultura organizacyjna pozwala im na niezależne myślenie, wykorzystuje ich wiedzę, doświadczenie oraz motywację do jak najlepszego działania całej organizacji. Teoria zarządzania nazywa ten proces empowermentem, czyli stworzeniem klimatu organizacyjnego, który uwalnia te drzemiące w pracownikach pokłady [Blanchard 2014, s. 57-58]. Ken Blanchard twierdzi słusznie, że utrzymanie kultury empowermentu wymaga samokontroli lidera w ograniczaniu swoich zakusów do przywracania hierarchicznie pojmowanego przywództwa. Z drugiej strony przeniesienie odpowiedzialności za wiele decyzji w procesie na pracowników może im dać niesłuszne poczucie, że mogą podejmować też kluczowe decyzje. Te ryzyka nie zmieniają jednak faktu, że proces ten wpływa ożywczo na organizację i daje pracownikom, zaangażowanym i mającym wpływ na proces oraz jego rezultaty, poczucie spełnienia [Blanchard 2014, s. 59].

Okazuje się, że idea dobrej komunikacji w zespole nie może polegać jedynie na byciu uprzejmym, wspierającym, empatycznym dla współpracowników. Nie 
zapewnią jej same spotkania. Komunikacja musi zostać wlana we właściwą dla danej organizacji formę i obudowana narzędziami i procedurami wspierającymi. Formą stało się zdefiniowanie Teatru Muzycznego jako w przeważającej mierze organizacji projektowej działającej w sektorze kreatywnym, co narusza poniekąd utartą wizję tradycyjnej instytucji kultury. W związku z czym konieczne było uelastycznienie procedur w kierunku organizacji zwinnej. Program Asana ułatwił nam to znakomicie, choć proces ten jest cały czas rozszerzany na inne narzędzia współpracy. W okresie pandemii konieczne stało się też zakupienie dodatkowych komputerów niestacjonarnych, by umożliwić elastyczną wymianę osób pracujących zdalnie i stacjonarnie. Model komunikowania się na wspomnianych spotkaniach gdzie inicjatywa nie wychodzi od lidera całego zespołu - wpływa też na zmianę codziennych interakcji zawodowych. Zauważalne jest przejmowanie inicjatywy przez zespół, gdyż w modelu tym lider pozostawia członkom zespołu miejsce na rozwiązanie problemów czy podjęcie uzgodnień usprawniających, a to zwiększa ich inicjatywę w proponowaniu nowych rozwiązań. Jest to możliwe w zgranym, przeszkolonym zespole. Nowy pracownik wymaga zawsze dodatkowych spotkań o charakterze instruktażowym.

Chyba najbardziej dobitnym przykładem zmiany kultury organizacyjnej jest przebieg koordynacji, najważniejszego dla planowania pracy teatru cotygodniowego spotkania, oraz szczegółowość zapisu planu omawianego w dwutygodniowym cyklu. W okresie zarządzania hierarchicznego i dużych zmian organizacyjnych koordynacja była prowadzona przez lidera na podstawie planu przygotowywanego przez koordynatora. Liczba osób zabierających głos była niewielka. Wyznaczano zadania, pytano o problemy, akceptowano plan do wykonania. Plan prób i spektakli zawierał ogólne informacje o godzinach rozpoczęcia i prowadzenia prób oraz nazwiska prowadzących. Dziś koordynację prowadzi koordynator, a nawet zastępca koordynatora. Pyta on poszczególnych kierowników lub samodzielnych pracowników o ich ocenę planu, pojawiające się wątpliwości i możliwe modyfikacje. Rola lidera ogranicza się do słuchania i korygowania $w$ momentach, gdy na przykład realizacja planu nie uwzględnia zasadniczych celów lub zagraża ich realizacji. Lider posiada pełniejszy ogląd sytuacji, którym dzieli się z zespołem, by uzmysłowić sens podejmowanych detalicznych działań lub zbudować dla nich kontekst. Komunikacja ma charakter otwarty, zachęcający do zadawania pytań i dzielenia się wątpliwościami, które mają szansę być wyświetlone z odpowiednim wyprzedzeniem i wpłynąć na planowanie.

Plan pracy zagęścił się i ma dużo bardziej dokładny charakter. Pojawiają się nazwy projektów realizowanych równolegle, kategorie osób biorących udział w próbach lub konkretne nazwiska członków zespołów. $Z$ uwagi na prowadzenie równoległych projektów zmianie uległ klasyczny układ pracy każdego zespołu w swojej sali. Próba opisywana jest czasem scenami ze spektaklu, by osoby nieuczestniczące w jej części mogły pracować nad innymi zagadnieniami, na przykład mieć indywidualne lekcje śpiewu, uczestniczyć w nagraniach. Planowanie często zaczyna się od uwzględnienia 
możliwości technicznych danego projektu artystycznego, co diametralnie skróciło uprzednio notoryczną pracę $\mathrm{w}$ nadgodzinach brygady obsługi sceny.

Indywidualne regularne spotkania lidera $\mathrm{z}$ kierownikami działów nie powinny zaniknąć, mają bowiem zupełnie inny charakter i dotyczą spraw kierunkowych, personalnych lub związanych z pracą i problemami danego zespołu, których nie można omawiać na forum. Spotkania takie pomagają też zwiększyć klarowność komunikacji. Nie każdy lider, podobnie jak nie każdy człowiek, ma umiejętność precyzyjnego formułowania myśli i oczekiwań. Otwartość komunikacyjna zazwyczaj powoduje, że druga strona ma odwagę wyartykułować, iż nie rozumie komunikatu lub ma wątpliwości w zakresie zasadności decyzji bądź kierunków działania.

Komunikacja wewnątrz organizacji dotyczy też procesu zmian, który się w niej odbywa. W Teatrze Muzycznym w Poznaniu ta zmiana miała fundamentalny charakter. Zbudowanie narracji wokół tego procesu stało się niezmiernie istotne (tzw. storytelling). Komunikacja zmiany powinna się odwoływać do emocji i przekonań, do dumy z tego, że tworzymy wyjątkowy program, wyjątkową organizację. Musi też odpowiadać na pytania: po co nam zmiana, czy jest faktycznie potrzebna, czy jesteśmy w stanie ją wdrożyć? Powinna też dawać komunikaty o wsparciu, jakie jest i będzie udzielane, oraz na temat indywidualnych korzyści dla pracowników, co uzasadni oczekiwanie ich pełnego zaangażowania.

W bieżącym wirze działań umyka często istotny element: uaktualniania misji organizacji i jej zasadniczych celów. Muszą one uwzględniać rezultaty wdrażanych zmian. Wymaga to - co nie jest łatwe - zatrzymania się i refleksji, wymaga spotkań zarządu, a następnie zarządu z kierownikami działów, i rozmów przekraczających bieżące planowanie i rozwiązywanie problemów.

\section{Tworzenie i rozwój zespolu}

Powyżej opisany sposób działania domaga się również wsparcia kierowników lub szerszego grona pracowników przez szkolenia czy inspirujące spotkania. Inwestycja w zasoby ludzkie jest najlepszą inwestycją dla organizacji, która wiąże z nią najlepszych pracowników. Warto też znajdować czas na spotkania o charakterze nieformalnym, ocieplające relacje, które na co dzień obarczone są stresem i ciągłym nastawieniem na osiąganie celów w czasie, którego często brakuje. Zakładając, że liderzy w zespole pracują więcej niż 8 godzin dziennie, że komunikują się w sprawach zawodowych również po godzinach, że żyją pracą, forma spotkania o innym charakterze, $w$ innym miejscu niż teatr, ma głęboki sens i wpływa pozytywnie na relacje stricte zawodowe. Stwarzanie możliwości rozwoju pracowników jest najlepszym sposobem wpływania na ich pozytywną motywację. Ponad rok temu 12 osób z zespołu Teatru Muzycznego wzięło udział w szkoleniu prowadzonym przez Pawła Motyla, wieloletniego szefa Harvard Business Review Polska. Po inspirującej części 
wykładowej zostaliśmy poproszeni o komentowanie problemów w zarządzaniu firmą, które opisywały grupy menedżerów - gospodarzy szkolenia. Sama konstatacja, że inne organizacje mierzą się z podobnymi problemami jak my, była dla nas ważna. Okazało się również, że podejście pracowników teatru do tych samych problemów jest bardzo kreatywne.

Przy pojawiających się obecnie problemach komunikacyjnych lub zarządczych naturalna staje się rekomendacja o skorzystaniu z pomocy coacha lub przeprowadzenie treningu, szkolenia czy warsztatów dla zespołów artystycznych.

W momencie wyłonienia się i sprawdzenia w działaniu wielu liderów przejmują oni koordynację poszczególnych projektów i zespołów projektowych. Mogą też stać się liderami zmian. A zmiany mają i powinny mieć charakter ciągły, na przykład w obszarze nowych technologii czy komunikacji. Dużą trudność stanowi monitorowanie nastawienia zespołów do poszczególnych liderów przez udzielanie regularnych informacji zwrotnych. Mogą oni mieć świetną komunikację z liderem organizacji, oceniającym ich działania na tej podstawie, ale słabą, nieproduktywną czy wręcz destrukcyjną ze swoimi współpracownikami. Należy znaleźć sposób uzyskiwania informacji od członków zespołu, a w tego typu sytuacjach informować taką osobę o wiedzy na temat problemów, podjąć się jej osobistego coachingu lub spróbować go zapewnić z zewnątrz. W skrajnej sytuacji konieczne staje się odsunięcie z kluczowych stanowisk osób, które nie mają predyspozycji przywódczych lub blokują zmiany.

Proces otwartej komunikacji, połączony z dbałością o rozwój pracowników i wyłuskiwaniem ich talentów, które mogą stać się kluczowymi kompetencjami, niewykorzystywanymi wcześniej, prowadzi do awansu. Zasadą przyjętą w praktyce zarządzania zespołem w teatrze stał się wewnętrzny awans pracowników na bardziej odpowiedzialne stanowiska: tancerz z wykształceniem pedagogicznym i menedżerskim został kierownikiem baletu, asystentka dyrekcji - szefowa sekretariatu - kierownikiem projektów, pracownica sekretariatu - pracownica koordynacji - koordynatorem pracy artystycznej, młody pracownik brygady technicznej z wykształceniem logistycznym, po szkoleniu między innymi z rysunku technicznego - kierownikiem technicznym, pracownica marketingu - samodzielnym pracownikiem ds. produkcji i impresariatu, pracownica marketingu - kierownikiem marketingu, tancerz z wykształceniem choreograficznym - choreografem, doświadczony aktor - asystentem reżysera, inspicjentem czy reżyserem mniejszych produkcji. Inspiracją dla takiego działania jest zasada wyrażona przez Jima Collinsa: najpierw kto, potem co (first who than what) [Collins 2007]. Lider zaprasza do współpracy te osoby, u których rozpoznał predyspozycje osobowe lub które w jakiś sposób sprawdził w działaniu. Jeżeli w dłuższym okresie się nie sprawdzają, nie kontynuuje współpracy. Przypisywanie konkretnych obszarów czy zadań jest wtórne i często korygowane po czasie. Gdyż to nie szczegółowe kompetencje, mimo że ważne, są największą wartością, ale cechy charakteru, ogólny rys osobowości i zdolność do brania współodpowiedzialności za organizację. 
Przykładem podręcznikowym jest pozyskanie obecnego szefa zespołu tanecznego Teatru Muzycznego w Poznaniu. Był on zbliżającym się do czterdziestki tancerzem, u którego nie podejrzewałbym aspiracji i talentów przywódczych. Ponieważ w 2009 roku polski rząd podniósł wiek emerytalny, a także zlikwidował obniżony wiek emerytalny dla artystów, w tym tancerzy (wcześniej 45 lat, po zmianie 67 lat sic!), podjął on wysiłek ukończenia studiów, cały czas pracując w teatrze. Niedługo po ich ukończeniu zaproponował mi, że podejmie się zarządzania zespołem, w którym postępował kryzys przywództwa oraz dochodziły do głosu frustracje związane z ograniczeniem samodzielnej roli baletu w teatrze musicalowym oraz koniecznością zmniejszenia jego stanu osobowego, czego nie mogła zrozumieć i zaakceptować poprzednia liderka zespołu.

Rodziło się kilka zagrożeń, w tym ryzyko, że nowy kierownik nie poradzi sobie z zadaniem, co spotęguje słabe wówczas zaufanie zespołu do dokonującego zmian lidera. Ryzyko to musiało zostać rozłożone na dwie strony. Umówiliśmy się od początku na dwuetapowy okres próbny: (1) przyjęcie funkcji pełniącego obowiązki tymczasowego kierownika zespołu na cztery miesiące, a następnie (2) rozwiązanie umowy o pracę na czas nieokreślony jako tancerza i podpisanie dwuletniego kontraktu na stanowisko kierownika zespołu z trzymiesięcznym okresem wypowiedzenia.

Ryzyko to w pełni się opłaciło, gdyż odkryty talent liderski się rozwinął. Naturalne zmiany personalne w zespole spowodowały, że osoby nieakceptujące nowego kierunku rozwoju odeszły. Nowy kierownik jest dziś kluczowym współpracownikiem, znającym doskonale teatr. Podejmuje się również wchodzenia w odpowiedzialną rolę inspicjenta przy spektaklach. Posiada też wysoką motywację do dzielenia się swoją wiedzą i umiejętnością planowania procesu pracy artystycznej, co ujawnia podczas cotygodniowych spotkań koordynacyjnych.

Innymi przykładami są: utrata byłej kierownik marketingu i zatrzymanie osoby obecnie zarządzającej projektami. Stanowisko to wcześniej nie istniało, a szef marketingu zarządzał jednocześnie projektami. Było to wówczas najbardziej przeciążone stanowisko w organizacji. Teatr, obok przygotowywania premier i grania spektakli repertuarowych, rozszerzał regularnie zakres swojej działalności. Doszliśmy wówczas do tego, że projektowy model działania nowoczesnej instytucji kultury jest najadekwatniejszy do wyzwań stojących przed nią. Organizowanie projektów, na przykład dużego koncertu z Placido Domingo, superprodukcji Jesus Christ Superstar na stadionie w Poznaniu czy bożonarodzeniowych koncertów telewizyjnych, budziło jednak wiele emocji. Zespół administracyjny nie był odpowiednio liczny i przeszkolony w tym zakresie. Zadania projektowe nakładały się na rutynę działań administracyjnych. Szwankowała komunikacja. Rodziły się konflikty. Pozostawały „pola niezagospodarowane”, które swym działaniem obejmować musiała szefowa marketingu, przy słabo zmotywowanym do współpracy zespole, który nie angażował się poza wyznaczony zakres obowiązków. 
Wówczas szefowa marketingu i projektów, przeciążona pracą, postanowiła odejść. Nie byliśmy wówczas gotowi jej zatrzymać, gdyż dopiero zaczynaliśmy wdrażać nowy model zwinnego zarządzania teatrem przy udziale skromnego wsparcia technologicznego. To wsparcie okazało się jednak kluczowe. Również inna ambitna osoba zakomunikowała, że chce się rozwijać, i dlatego zaczęła szukać nowej pracy. Na szczęście, wraz ze współpracującym wówczas z nami trenerem, byliśmy w stanie nazwać wraz z nią problemy, jej oczekiwania i aspiracje - i podjąć decyzję o stworzeniu nowego kluczowego stanowiska w strukturze: kierownika projektów. Osoba ta wróciła do kluczowych dla niej praktyk, między innymi posługiwania się w pracy językiem angielskim, by wkrótce otrzymać prowadzony po angielsku projekt produkcji premiery we współpracy z twórcami z USA. Otrzymała również zadanie wdrożenia, opartego na koncepcji zwinnego zarządzania, systemu spotkań projektowych, w celu wyjścia z biurokratycznych schematów działania w polu wyłącznie swojego zakresu obowiązków. Okazała się świetnym liderem likwidującym obszary „niezagospodarowanego pola” w projektach, nazywającym pola wymagające wsparcia szkoleniami. Dzięki jej zdolnościom zespół zaadaptował model działania zwinnie zarządzanej organizacji projektowej.

Samo przełamanie bariery mentalnej, związanej z koniecznością dużo częstszego niż wcześniej i aktywnego uczestnictwa w spotkaniach, konkretnego referowania za każdym razem przebiegu realizacji swoich zadań, było dużym wyzwaniem. Charakter spotkań w teatrze zmienił się diametralnie. Po pewnym okresie i docenieniu roli tej metody pracownicy przestali się bać przyjmowania na siebie zadań koordynowania projektów czy prowadzenia spotkań. Nabrali bowiem poczucia i utrwalili w swojej świadomości, że dzięki tej metodzie działania i wspomagającemu ją programowi oraz wsparciu ze strony kierownika projektów czy dyrekcji teatru są w stanie osiągać założone cele. Koordynacja projektów została też wsparta systemem premiowania, co nie jest proste w publicznej instytucji kultury. Jest jednak niezmiernie istotne.

\section{0d przywództwa sytuacyjneģo do przywództwa slużebnego}

Model przywództwa w instytucji kultury, szczególnie artystycznej, wydaje się kluczowy. Obserwuje się wciąż w wielu organizacjach czy uczelniach artystycznych funkcjonowanie hierarchicznego i autorytarnego modelu zarządzania. Stanowi on dość archaiczny sposób przewodzenia, szczególnie organizacjom kreatywnym. Hierarchiczność może stwarzać duże ograniczenia dla uruchomienia we współpracownikach pokładów kreatywności i chęci brania przez nich współodpowiedzialności za organizację. Model ten okazuje się wówczas nieadekwatny i nieskuteczny. Niestety jego nieskuteczność nie jest weryfikowana w racjonalny sposób. Dlatego w sektorze publicznym utrwalać się może krytykowany model, który powinien zostać zarzucony. Celem przywództwa jest prowadzenie organizacji w taki sposób, 
by mogła skutecznie i z sukcesem realizować swoje wyjątkowe cele. Komunikacja i kultura organizacyjna mają w tym procesie kluczowe znaczenie. Ale kluczowe znaczenie mogą mieć kompetencje przywódcze i samoświadomość lidera, które należy rozwijać.

Model przywództwa tworzy w dużym stopniu kulturę organizacyjną. Ta zaś ma z kolei wpływ na rodzaj i jakość komunikacji w zespole. Większość pojawiających się mankamentów w tych zakresach wynika $\mathrm{z}$ niedoskonałego i nieświadomego przewodzenia. Uczenie się przywództwa odbywa się również przez popełnianie błędów, do których warto czasem się przyznać przed zespołem w celu przekroczenia progu zaufania, który buduje nową jakość w relacjach.

Tytułowe pojęcia zaczerpnięte są z książki przywoływanego już Kena Blancharda Przywództwo wyższego stopnia. Przywództwo sytuacyjne opiera się na założeniu stosowania w zarządzaniu wspominanego już empowermentu, a więc przeniesienia punktu ciężkości w zarządzaniu na współpracowników i ich współodpowiedzialności za organizację i osiągane rezultaty. Opiera się też na elastycznym używaniu różnych stylów przywództwa i dostosowywaniu ich do danej sytuacji, a przede wszystkim do różnego poziomu zaawansowania i predyspozycji współpracowników. Wyróżnia etapy rozwoju pracownika i dostosowanie do nich adekwatnych działań lidera, rozpiętych na dwóch osiach zachowań: instruujących i wspierających.

Lider mający do czynienia $\mathrm{z}$ „entuzjastycznym debiutantem” instruuje go, stosuje metodę konsultowania wobec „rozczarowanego adepta”, wspiera „kompetentnego, lecz ostrożnego praktyka” albo deleguje zadania „samodzielnemu ekspertowi” [Blanchard 2014, s. 76-81]. Koncepcja przywództwa sytuacyjnego stanowi ważne narzędzie w prowadzeniu współpracowników. Każe liderowi pomagać współpracownikom w takim zakresie, w którym oni sami nie są w stanie poradzić sobie $\mathrm{z}$ danym zadaniem.

„Przywództwo składa się z dwóch elementów: wizji i jej urzeczywistnienia”, pisze Blanchard [2014, s. 209-210]. Efektywne przywództwo zaczyna się od nazwania najważniejszych wartości, którymi się kieruje, gdyż właściwy rodzaj przywództwa nie dotyczy tylko stylu, ale też jego charakteru i intencji. „Skuteczne przywództwo ma swój początek w duchowym wnętrzu człowieka, a właściwym rodzajem przywództwa jest przywództwo służebne. Nie bierze się ono z fałszywej dumy ani z lęku - jego źródłem jest pokora i nakierowanie na większe dobro". Można zatem powiedzieć, że już techniczne w swym wymiarze zarządzanie sytuacyjne ma charakter służebny, gdyż dostosowuje się do poziomu zaawansowania członków organizacji i „kładzie nacisk na wydobycie z ludzi drzemiącej w nich wielkości" [Blanchard 2014, s. 209-210].

Przywództwo służebne stanowi całkowite odejście od egocentrycznego przywództwa, które polega na służeniu samemu sobie. Dobry lider jest jak dojrzały człowiek, który „osiąga dorosłość, kiedy zdaje sobie sprawę, że życie polega na tym, żeby dawać, a nie brać”. Gordon MacDonald [2003, s. 222] różnicuje przywódców na tych „z motywacją", która nie jest wystarczająca, i „z powołaniem”. Z kolei Ken 
Blanchard i Mark Miller [2004] rozszyfrowują zaproponowany przez MacDonalda akronim SERVE jako:

S - See the Future - ujrzyj przyszłość,

E - Engage and Develope People - angażuj i rozwijaj pracowników,

$\mathrm{R}$ - Reinvent Continuously - doskonal się ciągle,

V - Value Results and Relationships - ceń wyniki i relacje międzyludzkie,

E - Embody the Values - ucieleśniaj wartości.

Przewodzenie zespołowi nie jest łatwym zadaniem. W instytucji artystycznej dodatkową trudność stanowić może kierowanie zespołem wrażliwych i często bardzo indywidualistycznie nastawionych artystów, którzy nieustannie domagają się akceptacji i pochwał. W pewnym sensie są uzależnieni od braw widowni. Wyjątkowy stres, który jest związany z występowaniem na scenie, jest rekompensowany natychmiastową informacją zwrotną w postaci braw, pochwał, wpisów fanów w mediach społecznościowych. W zarządzaniu takim zespołem bardzo łatwo o nadużycia i granie na emocjach.

Jim Collins w swojej koncepcji przywództwa piątego stopnia [Collins 2007] rozbraja mit idealnego lidera jako herosa i egocentrycznego przywódcy. Określenie to oznacza najwyższy w jego pięciostopniowej skali rozwój kompetencji liderskich. Collins - na podstawie badan - kreśli przekonujący portret cech osobowościowych i zdolności, niezbędnych do pełnienia funkcji skutecznego przywódcy, który jest jednocześnie odmienny od tego, co podpowiada nam intuicja. Według niego atrybuty przywódców piątego stopnia to paradoksalnie: osobista skromność, niezłomna wola działania, zdecydowanie oraz skłonność do przypisywania zasług innym i brania winy za niepowodzenia na siebie. Autor ilustruje swoją teorię barwnymi opowieściami o jedenastu przywódcach tego rodzaju, odnoszących sukcesy w najnowszej historii amerykańskiego biznesu. Zestawia niezwykłe rezultaty, osiągane przez tych niepozornych lub wręcz nieśmiałych ludzi, takich jak Colman M. Mockler z Gillette czy Darwin E. Smith z Kimberly-Clark, z tym, co osiągnęli i jak działali zabiegający o osobistą popularność słynni przedsiębiorcy w rodzaju Lee Iacokki - prezesa Chryslera. Collins przyznaje, że nie ma recepty na to, jak stać się przywódcą piątego stopnia, a nawet nie wie, czy jest to w ogóle możliwe. Niektórzy przywódcy mają według niego potrzebną do tego osobowość. Powołując się na wyniki badania, sugeruje jednak, że menedżerowie mogą starać się zmierzać w kierunku przywództwa piątego stopnia, stosując kilka zasadniczych sposobów działania - między innymi zatrudniając odpowiednich ludzi (zasada: first who than what) czy budując w organizacji kulturę dyscypliny.

Połączenie koncepcji Collinsa i koncepcji przywództwa służebnego wydaje się niezwykle inspirujące. Ta ostatnia nie jest techniką zarządzania, lecz bardziej nakazem etycznym, wynikającym z wartości, którymi kieruje się lider. Ale konsekwencjami 
takiego modelu przywództwa może być jednocześnie wzrost efektywności zarządzania i wzrost efektywności organizacji, która jest prowadzona we właściwy sposób. Jak pisał Władysław Bartoszewski [2005], rozwijając tytuł swej książki Warto być przyzwoitym: $\mathrm{z}$ jednej strony to nakaz moralny, z drugiej postępowanie, które w długiej perspektywie zwyczajnie się opłaca. Jednym z kluczowych czynników, które odpowiadają za zdolność bycia służebnym liderem, jest pokora. Jak celnie punktuje to Ken Blanchard [2014, s. 221]: „Ludzie pokorni nie myślą o sobie źle, oni po prostu myślą o sobie mniej”.

Po szkoleniu, w którym uczestniczyłem w 2020 roku, zastanowiło mnie używanie przez trenerów, których szanuję, pojęcia: „empatii taktycznej”, którą winien stosować skuteczny lider wobec swoich pracowników. Po głębszym namyśle uważam samo używanie tego pojęcia za antyhumanistyczne i szkodliwe. Postawa z niego wynikająca powodować może utylitarne traktowanie pojęć i zachowań, zarezerwowanych w świecie relacji międzyludzkich dla bezinteresownych działań i odruchów. Poza tym wiarygodność lidera powinna opierać się na tym, że budowane przez niego relacje potrafią być autentyczne, a wartości przez niego wyznawane mogą skutkować budowaniem relacji odniesionych do czegoś więcej niż utylitarnych potrzeb organizacji.

Wiarygodność lidera, może szczególnie publicznej instytucji kultury, może się zasadzać na koncepcjach Collinsa i Blancharda, a szczególnie na koncepcji przywództwa służebnego. Propozycja ta dobrze odpowiada misyjnemu czy społecznemu charakterowi działalności prowadzonej przez instytucje kultury. Ważne, by ta misyjność była również argumentem za najwyższą jakością zarządzania i przywództwa. Model ten, czy ideał, nie jest łatwy do realizowania i stanowi codzienne wyzwanie dla autora, jak i wielu świadomych liderów.

\section{Bibliografia}

Bartoszewski W. (2005), Warto być przyzwoitym. Szkice osobiste i nieosobiste, Poznań: W Drodze. Blanchard K. (2014), Przywództwo wyższego stopnia. Blanchard o przywództwie i tworzeniu efektywnych organizacji, tłum. A. Bekier, Warszawa: PWN.

Blanchard K., Miller M. (2004), The Secret: What Great Leaders Know - and Do, San Francisco: Berrett-Koehler Publishers.

Blanchard K., Peale N.V. (1988), The Power of Ethical Management, New York: William Morrow. Cameron K.S., Quinn R.E. (2003), Kultura organizacyjna - diagnoza i zmiana, Kraków: Oficyna Ekonomiczna.

Collins J. (2007), Od dobrego do wielkiego. Czynniki trwałego rozwoju i zwycięstwa firm, Warszawa: Wydawnictwo MT Biznes.

Diagnoza kultury organizacyjnej Teatru Muzycznego w Poznaniu. Zespołowy projekt konsultingowy (2016), przeprowadzony w ramach programu Master of Business Administration, 
prowadzonego przez Uniwersytet Ekonomiczny w Poznaniu. Autorzy: Marcin Halczyński, Maciej Leciejewski, Kamil Nawrocki, Agata Daleszyńska-Slater. Materiał niepublikowany, w zasobach Teatru Muzycznego w Poznaniu, Poznań 2016. Przy wdrożeniu rekomendacji, które wyniknęły z badania, z Teatrem współpracowały Agata Daleszyńska-Slater i Jagoda Szulia.

MacDonald G. (2003), Ordering Your Private World, Nashville: Nelson Books. 